\title{
Editorial
}

\section{Corporate Tax Planning and Financial Performance of Quoted Food and Beverages Firms in Nigeria}

\author{
Oyeshile Oladapo Kayode, Adegbie Festus Folajinmi
}

Department of Accounting, Babcock University, Ilishan-Remo, Nigeria

Email address:

oyeshilekayode@yahoo.com (O. O. Kayode)

\section{To cite this article:}

Oyeshile Oladapo Kayode, Adegbie Festus Folajinmi. Corporate Tax Planning and Financial Performance of Quoted Food and Beverages Firms in Nigeria. Journal of Finance and Accounting. Vol. 8, No. 6, 2020, pp. 266-275. doi: 10.11648/j.jfa.20200806.13

Received: August 12, 2020; Accepted: October 5, 2020; Published: November 23, 2020

\begin{abstract}
This study evaluated the effect of corporate tax planning on the financial performance of Quoted food and beverages firms in Nigeria, with a population comprising 15 quoted food and beverages firms on the Nigerian Stock Exchange for ten years between 2008-2018, forming the sample using total enumeration sampling method. The study employed ex-post facto research design. The validity and reliability of the instruments were based on the statutory audit of the financial statement and approval for use by the regulator. The data were analysed using descriptive and influential statistics. From the analysis done, it has shown that corporate tax planning variables of effective tax rate, capital intensity, thin capitalization do not have a significant positive effect on financial performance of a quoted food and beverages firm in Nigeria Adjusted $R^{2}=0.069$ : F-statistic $($ input $)=8.81, p=$ $0.0383<0.05$ ). The analysis revealed that all proxies of corporate tax planning practices do not significant effect on return on capital employed of quoted food, and beverages firm in Nigeria (Adjusted $R^{2}=0.038:$ F-statistic $1.09, p=0.03537>0.05$ ). All proxies of corporate tax planning practices have a significant positive effect on return on assets of the industry (Adjusted $R^{2}=$ 0.1095: F-statistic 37.76, $p=0.000<0.05$ ). All proxies of corporate tax planning practices have no significant effect on return on equity of the industry (Adjusted $R^{2}=0.0068$ : F-statistic $0.66, p=0.957>0.05$ ). Similarly, the result shows all proxies of corporate tax planning practices do not have a significant positive effect on earnings per share of the food and beverages industry (Adjusted $R^{2}=0.068: F$-statistic $1.34, p=0.2639>0.05$ ). Thus, the research concluded that corporate tax planning proxies of effective tax rate, capital intensity and thin capitalisation, has a significant positive effect on the performance of quoted food and beverages firms in Nigeria.
\end{abstract}

Keywords: Earnings Per Share, Effective Tax Rate, Return on Capital Employed, Return on Asset, Return on Equity, Thin Capitalisation, Profitability

\section{Introduction}

The financial performance of business organization worldwide has elicited concerns from both academicians and professionals especially in the foods and beverages industry of most economies. Financial performance of firms can be described as an economic measure that reflects the market value of a whole business.

In Europe, there was a research on financial participation and position and a position the outcome of performance [47]. Data was taken from Finland, Germany, Netherland and United Kingdom, various measures was used and the outcome put some doubt on financial and other forms of participation.
In Nigeria, with the introduction of information technology tax, there are about forty different taxes levied on food and beverages companies which hinder companies return on asset, liquidity and return on capital employed [7, 37]. All these taxes from various government levels overlap and are forcefully extracted from corporate organization's profitability.

Nigerian government undertook various tax law reforms to improve tax administration, to increase tax yield: Federal Board of Inland Revenue Services (Establishment) Act 2007, National Tax Policy of 2017, to address the issue of multiple taxation, lack of accountability for tax revenue and expenditure, use of aggressive and unorthodox method for tax collection. The FBIR Act 2007 was to grant autonomous to 
Federal Board of Inland Revenue to perform her duties, of administration of taxes, by ensuring that collection and collation of tax revenue are efficiently and effectively done. The Board of Inland Revenue administers the federally collected taxes through the Federal Inland Revenue Service (FIRS), while the board of state internal revenue service administers the taxes collectible by the state government and the revenue committee administers taxes and levies collectible by the Local governments [24]. Other temporary reforms are Voluntary Assets and Income Declaration Scheme (VAIDS Executive order No. 004 of 2017) and Voluntary Offshore Assets Regulation Scheme (VOARS Executive order No. 008 of 2018) [13]. The two are tax amnesty for those who voluntarily declare to enjoy immunity from prosecution, freedom of interest and penalty, come clean and start complying while VAIDS is for anybody within the country. Tax payers who make full and honest declarations will enjoy waiver of interest and penalty, immunity from prosecution, confidentiality, exemption from tax audits for the periods covered and flexible payment of tax due According to pwc-tax-alert-volume 9. june 2017; VOARS is for off shore and high income earners. These government interventions of VAIDS, VOARS, though temporal but they a meant to expand the tax net, through the encouragement of tax payers and recover part of debt of the past which invariably leads to additional revenue.

Tax Planning is a conscious effort on the part of the tax payer to eliminate or reduce or spread tax liability without going against the law, by using all available allowances, exemptions, policies, guidelines, incentives and relief (Tax Avoidance). There is need to have an in-depth knowledge of policies and regulations spelt out in the government fiscal policies for an effective tax planning. The incentives specified in CITA, PITA and other laws include the following; commencement rule, investment allowance, pioneer status, cessation rule, investment allowance, exemption on interest on loan to foreign company wanting to do business in Nigeria and the timing of asset acquisition, claims of capital allowance.

The corporate objective of any organization is to maximize shareholder's value. Tax Evasion is the fraudulent criminal act under tax laws, dishonest, intentional distortion or concealment of facts and figures with the intention of avoiding the payment of or reducing the amount of tax otherwise payable. These acts of omission or commission might include: failure to pay tax e.g. withholding tax; failure to submit returns; omission or misstatement of items from returns; claiming relief (in Personal Income Tax), for example, of children that do not exist; understating income; documenting fictitious transactions; overstating expenses; failure to answer queries [33].

Up till now, tax avoidance is still one of the important issues in the global economy that almost every country still struggles to fight [55]. (Khan and Safiuddin 2016), opined that poor management of tax planning of an organization increase tax evasion and tax avoidance which in turn run down firm's profitability [29]. Thus, the poor management of tax planning directly affects the results of a company's business [17].

Corporate tax planning are potential costs related to strategies to minimize taxes such as implementation and transaction costs, possible penalties imposed by the tax authorities and reputation risks that must be considered which in turn expose firms to extra cost of expenditure [37]. As noted) tax planning is very fundamental to the liquidity and profitability of any organization, which are vital to the survival of any organization [26].

There are many practices performed by companies in order to reduce the amount of their taxes. Firms employed capital intensity to manage high tax rate, tax avoidance and tax liability because the capital intensity is considered as an operational leverage which reduces operational costs by allocating much expense to fixed assets. In other words, since the firm has already distributed significant expenses among fixed assets, and these assets are for long term without any additional expense, consequently, the firm can completely reduce operational costs. Considering financial performance of manufacturing firms in Nigeria, the major challenge of food and beverages firms come in a midst of high corporate tax rates, poor tax planning and multiples of other taxes that lead to high effective tax rates far above the statutory company income tax rate thus adversely affect firm profitability, liquidity, returns and asset tangibility. With the introduction of the information technology tax, there are about forty different taxes levied on food and beverages companies which hinder companies return on asset, liquidity and return on capital employed [7, 36]. Many of these taxes from the different levels of government overlap and are forcefully extracted from corporate organizations profitability.

Furthermore,(Nwaobia, A. N. 2014) and (Nwaobia and Jayeoba 2016) emphasized that inefficient and ineffective tax administration in Nigeria instigate poor tax planning which have increase tax rate, tax evasion and tax avoidance among manufacturing firms in Nigeria thus adversely affect their financial performance [36, 37]. Based on these identified issues of poor tax planning among food and beverages firm in Nigeria, this study will investigate the effect of tax planning dimensions (effective tax rate, capital intensity and firm size) on financial performance of quoted food and beverages firm in Nigeria.

\subsection{Research Problem}

The financial performance is critical to the going concern of a firm. In Nigeria high tax rate and multiple taxation have a significant impact on the financial performance of the firm. This leads to management-shareholder conflict. Shareholders want long term wealth maximization while the management pursues other interest.

These higher tax liability and poor tax planning had reduced manufacturing companies' profitability, return on capital employed, return on equity and economic activities [37, 40]. (Tsado \& Gunu 2016) and Zwingina \& Opusunju 2017) pointed that poor tax planning strategies had triggered food and beverages manufacturing companies tax expenses which had reduced asset tangibility and return on equity of most food 
and beverages manufacturing companies in Nigeria $[55,60]$.

Generally, (Salawu, R., Ogundipe, L., \& Yeye, O., 2017). noted that manufacturing firms in Nigeria, especially multinationals, are using tax management initiatives to avoid paying some taxes [49]. They further asserted that food and beverages multinational firms maintained lower profit over the years due to their inefficient tax planning schemes. It is therefore important to not only understand the tax planning strategies but to also link tax planning to the financial performance of the food and beverages manufacturing firms in Nigeria. These past researches do not focus on determining the consequence of tax planning strategies on the fundamental key indices of financial performance, that is, return on capital employ, return on asset, return on equity, earnings per share, and the same time have not considered the tax planning and financial performance of quoted food and beverages firms in Nigeria.

There is a gap that the present study seeks to bridge by investigating an answer to the research question on how does corporate tax planning dimensions affect the financial performance indices of listed multinational food and beverages firms in Nigeria?

\subsection{Objective of the Study}

The main objective of this study was to evaluate the effect of corporate tax planning on financial performance of quoted food and beverages firms in Nigeria.

\subsection{Research Hypotheses}

Based on the above objectives, the following hypothese were tested in this study;

$H_{0} 1$ : Corporate tax planning does not have significant effect on return on capital employed (ROCE) in quoted food and beverages firms in Nigeria.

\section{Literature Review}

\subsection{Conceptual Review}

\section{Corporate Tax Planning}

Corporate tax planning is legitimate activities undertaken by firms to manage their income and expenses with the objectives of eliminating, minimising and deferring tax within the ambit of the tax laws [58]. (Pniowsky 2010) defined tax planning as the process of structuring one's affairs in order to defer, reduce or eliminate the amount of taxes payable to government [44]. Tax planning could be the legal steps taken by tax payers to lessen their tax burden in order to obtain tax savings benefits.

Tax planning involves the application of relevant incentive provisions for corporate tax payers based on enabling laws such as the CITA, PITA, VAT and other enactments. These laws provided some incentives such as pioneer status incentive, commencement rule, cessation rule, investment allowance, roll-over loss relief tax exemptions, deductions, rebate and other tax concessions allowed by tax statutes, which tax planning by organization can be built on.
According to (Nwaobia and Jayeoba 2016), tax planning activities can be considered as "active" or "passive" depending on the taxpayer's intentions in conducting a transaction [37]. (Yimbila, 2017) Posited that active corporate tax planning is relevant in a situation where a transaction is carried out with an aim to reduce the tax burden [58]. While passive tax planning is a situation whereby a transaction is carried out without an earlier intent or purpose to reduce the tax burden. Dada, S. 0. \& Adetola, R., 2017) stated that tax planning can lead to a reduction in firm value when managers have both the opportunity to undervalue reported accounting profit and the incentive to reduce company income tax liability by understating taxable income [12].

(Khalid et al. 2017) established the following as elements of corporate tax planning [28]

i. Planning to eliminate the tax, if that was legally permitted through tax exemptions.

ii. Benefitting from the costs that are subjected to tax deduction and using cost items that are subjected to deduction instead of using non-cost items, such as using funding by loans instead of self-funding.

iii.Postponing the date on which the tax shall be due to be paid as much as possible.

iv. Benefitting from all the tax exemptions that are stated in the tax law and the relevant laws.

v. Choosing the appropriate legal form for the relevant enterprise.

vi. Stated that corporate tax planning process is an ongoing process that its use is not restricted to a certain financial period.

Tax Rate

This is the rate that is applicable to different types of taxes as agreed by the government to be deducted from individuals, companies and services. Tax rate is the stipulated percentage that is backed by laws which taxpayers are expected to pay from their incomes. According to (Madugba, J.U., Ogbonnaya, A.K. \& Okpe I.I. 2016), direct tax is levied or imposed on the income, profits and properties of individual and corporate bodies. Indirect tax on the other hand is defined as taxes levied on goods and service rendered which are shifted in part or in full to either the final consumer who does not even know when he pays or the exact amount he pays [32]. However, the focus of this study is on company income tax, which is a direct type of tax.

It should be noted that tax rate is different countries by countries and according to the nature of the tax. The tax policies and legislations determines the tax rates of various forms of tax such as company income tax, petroleum profit tax, capital gain tax etc [2]. But the focus of this study is on corporate income tax. In Nigeria, tax rate has been fluctuating since the independence of Nigeria. The present tax rate in Nigeria as at the time of conducting this study are $30 \%$ for company income tax, $24 \%$ for personal income tax and $5 \%$ for value added tax.

According to (Gravelle and Marples 2014), (Ferede and Dahlby 2012), higher corporate tax rate negatively affect the profitability of the corporate organization but has good impact 
on government revenue and the growth of the economy [20, 16]. And the same could be said for income tax rate generally. Lower tax rate will enhance the purchasing power of the tax payers.

The higher the tax rate the lower the number of tax payer in the tax bracket. When the tax rate is higher it encourages tax evasion, and tax avoidance on the part of the tax payer. This means more revenue to government and relief also for the companies, this I think Nigeria government should follow.

\section{Capital Intensity}

Capital intensity is the amount of fixed or real capital present in relation to other factors of production, especially labour. At the level of either a production process or the aggregate economy, it may be estimated by the capital to labour ratio, such as from the points along a capital/labour isoquant [30]. According to (Mohammad, Mahmoud and Ensieh 2013), the capital intensity causes a decrease in the financial distress because the capital intensity is considered as an operational leverage which reduces operational costs by allocating much expense to fixed assets[35]. In addition,
(Gilbert Cette \& Jimmy Lopez \& Jacques Mairesse, 2016) proposed that capital intensity may have an improving role in the financial situation of the firm since capital firms keep a larger proportion of fixed assets compared to their opposite firms which can be used as an assurance that decreases the distress [18].

\section{Thin-Capitalization}

Thin capitalisation refers to the situation in where a company is financed through a relatively high level of debt compared to equity [46]. Thinly capitalized companies are sometimes referred to as highly leveraged or highly geared. The way a company is capitalized will often have a significant impact on the amount of profit it reports for tax purposes.

OECD (2012) defines thin capitalization as the strategy of a company to structure their financing with relatively high level of debt instead of equity, which sometimes referred to as 'highly leveraged'. High level of debt caused the company to pay a high amount of interest expenses.

Thin Capitalization

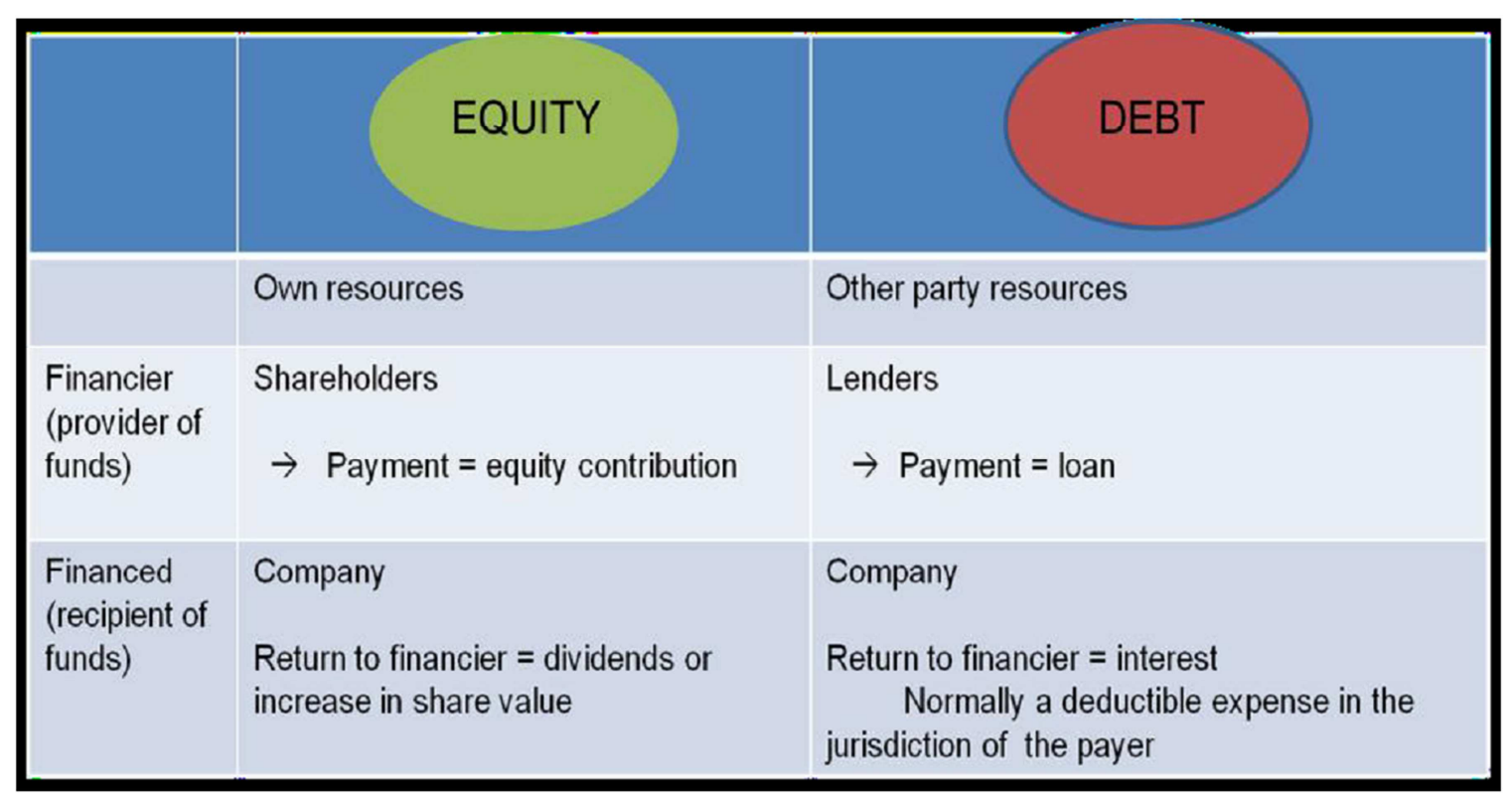

Source: Thin Capitalisation Adopted from OECD, 2012.

Figure 1. Thin Capitalization.

According to (Buettner et al, 2012), there are two approaches to designing thin-capitalisation rules: specific rules and non-specific rules. Specific rules explicitly restrict internal debt while nonspecific rules in most cases restrict debt in general (i.e. does not distinguish external debt from internal debt) [9].

Mathew Olusanya Gbonjubola [34], displayed how some countries have defined thin capitalization as safe harbour. The debt/equity ratio [34]:

i. USA, France - 1.5:1.

ii. Canada, Ghana - 2:1.

iii. Netherland, Australia, Japan, South Africa, Kenya - 3:1.

iv. China - Financial Institutions 5:1, Others 2:1.

v. Germany - deductibility of interest of up to $30 \%$ of income.

Firm Size

Firm size is defined as the value of the asset which the company has at any particular time [42]. (Babalola 2013) argues that the larger a firm is, the more the influence it has on its stakeholders, and so large firms tend to outperform small firms [6]. (Setiadharma and Machali 2017) posited that a big firm size is an indicator of a good growth of the firm; this will give positive signal to investor, which leads to an increase in firm value [50]. Firm size could be one of the most important factors which affect firm performance.

\section{Financial Performance}

Financial performance assesses the fulfillment of a firm's economic goals. Financial performance is an extent to which a 
company financial health over a period of time is measured [15]. Firm performance is the outcome of company's operational activities within a period under consideration. It is the result of the activities of a firm for a period(s) presented to the stakeholders. (Isabwa and Omete 2016) are of the opinion that measures of financial performance fall into two broad categories: investor returns and accounting returns [23]. The basic idea of investor returns is that, the return should be measured from the perspective of shareholders like share price and dividend yield. Accounting returns focus on how firm earnings respond to different managerial policies e.g. ROE and ROA. (Junaidu and Hauwa 2018) posited that a firm's high financial performance reflects its effectiveness and efficiency in the management of its resources for operational, investment and financing activities [25].

\section{Return on Capital Employed}

Return on capital employed (ROCE) is used for comparing the relative profitability of companies after taking into account the amount of capital used [8]. It is an accounting ratio expressing the profit of an organization for an accounting period as a percentage of the capital employed. (Ayman Mansour Khalaf Alkhazaleh, M. Al-dwiry 2018) asserted that ROCE is one of the most frequently used ratios for assessing the performance of organizations [5]. ROCE is calculated as: ROCE $=$ Earnings before Interest and Tax (EBIT) or Profit after Tax (TAX) / Capital Employed. The higher the ratio, the more efficiently the funds have been used by the management [45].

\section{Earnings per Share}

Is a popularly used financial performance variable. (Graham, Harvey and Rajgopal 2004) surveyed about 400 financial executives in the United State of America and reported that majority were of the opinion that earnings per share were the most important performance measure, they report to the outsider and also use for strategic decision making like valuation of shares, management performance incentive scheme and merger and acquisition [19]. (Ohlson and Juettner-Nauroth 2005) and (Taboga 2011), both confirm the continued relevance of EPS [41, 53]. (Adkins, Matchett \&Toy 2010) attribute the obsession with EPS to the fact that it neatly summarises the earnings generated for shareholders [3]. (Rappaport 2005) infers that short term EPS performance is especially important for younger companies for which future growth expectations are more sensitive to current performance [48].

\subsection{Theoretical Review}

\section{Hoffman's Tax Planning Theory}

This theory was propounded by Hoffman in 1961 . According to (Nwaobia \& Jayeoba, 2016) tax planning seeks to divert cash, which would ordinarily have flown to tax authorities, to the corporate entities [37]. Tax planning activities are desirable to the extent that they reduce taxable income to the barest minimum, without sacrificing accounting income. This theory believes that taxation are based on business or accounting concepts, therefore a firm can modify such activities towards the attainment of reduction in tax liability. The theory thus recognised a positive association between firm tax planning activity and firm performance. (Ogundajo and Onakoya 2016) asserted that Hoffmann identified some ambiguity and loopholes in tax laws due to unclear intentions of the legislators and concluded that successful tax schemes work with the legal concepts and precise wording of the statute and complying with these concepts very precisely as it relates to individual firm tends to be advantageous to firms in form of tax savings [40].

Agency Theory of Tax Planning

Agency theory was advanced by Jensen and Meckling in 1976s. (Slemrod 2004), (Chen and Chu 2005), (Crocker and Slemrod 2005) and (Tatu, Dragota and Vintila 2010) were among those scholars that view corporate tax planning within an agency framework $[10,11,14,51,54]$. The agency theory defines the relationship between the principal (shareholders) and the agent as well as defines responsibilities of agent. The theory is of the opinion that as representatives of the shareholders, managers are expected to act in such a manner that conforms to the shareholders interest.

Agency theory is management model where one individual (the agent) is given the legal right to act on behalf of another (the principal), could be a business owner, and the agent is expected to primarily advance the principal's goals. Political Power Theory

Political power theory was advanced by Siegfried in 1972 . (Stickney and McGee 1982); (Gupta and Newberry 1997) were among the supporters of this theory [21, 52]. (Zevenbergen 2018) gave three reasons support the principle of political power theory as it is related to taxation and tax planning [59]. Firstly, larger firms have more resources, which make it possible to influence the political process in their own advantage. Secondly, larger firms have more resources to acquire and hire tax planning experts. Thirdly, regulation of the company's activities on such a manner to optimize the tax savings is more possible by large companies with more resources.

\section{Stakeholder Theory}

This theory was first propounded in the 1984 century by Dr. Edward Freeman, a professor at Virginia university in his landmark book "Strategic Management: It considers creation of wealth for its owners and the maximization of both the importance of the firms interaction with its other constituencies and the role in the society as a major purpose for the establishment of any firm." According to (Nwaobia and Jayeoba 2016), shareholder's wealth can be maximized in the long-run when customers, employees and other stakeholders of the firm are satisfied [37]. The government becomes satisfied when appropriate taxes are remitted while the shareholders are satisfied if these taxes do not negatively affect the overall financial performance of their firm.

\subsection{Empirical Review}

This sector of this chapter focused on the findings on previous studies in line with the objectives that this study wants to achieve.

Performance can be explained in terms of how well an 
organization is managed and the value the organization is delivering to the customers and other stakeholders. Performance is also defined as the ability of an object to produce results in a dimension determined a priori, in relation to a target. According to (Owolabi and Makinde 2012), performance of an organization can be measured in reduction of environmental footprint, improved occupational health and safety performance, increased customer satisfaction [43].

According to (Nwaobia, A. N. 2014) taxes on corporate profits are mandatory and usually constitute a large outflow for firms that, if not planned, lead to disproportionate and unwilling transfer of corporate resources to the government with its negative impact on the operating capacity, firm value which is also a function of such corporate financial performance [36]. They concluded that wholistic approach to tax planning and optimal mix of tax planning strategies are important determinants of their effect on firm value(performance-oriented).

In the study conducted by (Olaoye and Bamisaye 2018) about the deferred tax and financial performance of firms in Nigeria and specifically analysing the effect of both deferred tax asset and deferred tax liability on firm's performance measured in terms of profit after tax, earnings per share, return on asset and return on equity [39]. 10 firms were sampled from the Nigerian stock exchange and data covering a period of 10 years within 2007 and 2016 and were analyzed by panel based estimation techniques. Result revealed that deferred tax asset and deferred tax liability exert negative impact on performance of firms. It thus stands that deferred tax practice by Nigerian firms has the tendency of impeding their prospect of sustaining improved performance, either when viewed from the purview of profit after tax, earnings per share, return on asset or return on equity.

(Dada and Adetola 2017) in concluding that tax planning has no significant effect on firms' performance [12]. They analysed that the Inability of tax payers to plan their taxes lead to high tax liabilities and companies in an attempt to avoid tax, end up paying more than what is statutorily required to tax fraudsters because they lack adequate knowledge of tax planning. (Kawor and Kportorgbi 2014) concluded that firms' tendency to engage in intensive tax planning activities reduces when tax authorities maintain low corporate income tax rates and that tax planning has a neutral influence on firms' performance, this is a finding that challenges the general perception that every form of tax savings from tax planning reflect in the pocket of investors and thus concluded that investors must institute systems to ensure tax planning benefits reflect significantly in their pockets [27].

\section{Methodology}

\section{Research design}

This research focused on the empirical analysis of relationship between corporate tax planning and financial performance with the aim of determining the impact of corporate tax planning on financial performance of food \& beverage companies in Nigeria. The research therefore adopted descriptive ex post facto research design since it relied on secondary data using panel data to establish the meaningful relationship between corporate tax planning and financial performance. This is appropriate because ex-post facto research aims at measuring and establishing the relationship between one variable and another or the impact of one variable on another. The required panel data were sourced from financial statements of selected and quoted foods and beverages firms on the Nigerian Stock Exchange for the period of 2008-2018. This period range allows for a more reliable findings and establishment of a trend analysis of long term relationship prediction of the interactions between the independent variable and dependent variable. The panel data analyses enabled the combination of temporal and spatial analysis, which made it possible to effectively analyse cross-sectional data.

\section{Population of study}

The target population for this study comprised of fifteen (15) quoted foods and beverages manufacturing firms on the Nigerian Stock Exchange as at December 2018. There are 15 firms under the foods and beverages industry as quoted on the Nigerian Stock Exchange as at this period. The foods and beverage industry was chosen for this research because of the sizeable growth of this industry, its sustain profitability and the possible change of the industry.

Table 1. Names of Selected and Quoted Foods and Beverages Firms in Nigeria.

\begin{tabular}{ll}
\hline S/N & $\begin{array}{l}\text { Name of Quoted Food and Beverages Firms in Nigeria Stock } \\
\text { Exchange }\end{array}$ \\
\hline 1. & Honeywell Flour Mills Nig. Plc \\
2. & Cadbury Nigeria Plc \\
3. & Dangote Flour Mills Plc \\
4. & Dangote Sugar Refinery Plc \\
5. & Mcnichols Plc \\
6. & Multiplex Integrated Foods Plc \\
7. & Flour Mills Nigeria Plc \\
8. & PZ Cussons Nig. Plc \\
9. & National Salt Co. Nigeria Plc \\
10. & Nestle Foods Nigeria Plc \\
11 & Unilever Nig. Plc \\
12 & Northern Nigeria Flour Mills Plc \\
13 & Tantalisers Nig. Plc \\
14 & FTN Cocoa Processors Plc, \\
15 & Union Dicon Salt Plc \\
\hline
\end{tabular}

Source: Nigerian Stock Exchange (2018)

\section{Sample Size \& Sampling Technique}

Since the number of listed foods and beverages firms in Nigeria was not so large and the present study was aimed to come up with a predictive model on how corporate tax planning affects firm financial performance of listed foods and beverages firms, all the 15 firms formed the sample. The approach was total enumeration sampling method

\section{Method of Data analysis}

The data analysis for this study was done in two ways: the descriptive and inference analysis. Descriptive analysis study employed quantitative method of analysis with the aid of Econometric View software. The study employed ex-post 
facto design and panel data methodology to examine the effect of corporate tax planning on financial performance of quoted food and beverages firms in Nigeria.

Panel data approach was used to measure the relationship between creative accounting and financial performance. The time series and cross-sectional data were analyzed based on fixed and random effect model, while Hausman test was used to select the best model. Fixed effect method is used to control all the static characteristics of the firms included in the study over a fixed period of time following the assumption of time series data. This technique removes biasness from the data and provides statistically better result by explaining only the variation within the sample. The Random effect method is applied on cross sectional data when the characteristics of sample differ. As one of the techniques of linear regression, its main function/goal is to closely fit a function with the data so as to minimize the sum of square errors from the data.

Model specification

In this study, there are two constructs; independent and dependent variables. Corporate tax planning as the independent variable is measure by effective tax rate (tax paid/profit before tax), capital intensity, thin-capitalization and firm size while the dependent variable is financial performance measure by return on capital employed, return on equity, return on asset and earnings per share. The model for the variables is denoted in the equations below:

$\mathrm{Y}=$ Dependent Variable

$\mathrm{X}=$ Independent Variable

$\mathrm{Y}=$ Financial Performance $(\mathrm{FP})=$ Dependent Variable

$\mathrm{y}_{1}=$ Return on Capital Employed (ROCE)

$\mathrm{y}_{2}=$ Return on Equity (ROE)

$\mathrm{y}_{3}=$ Earnings per Share (EPS)

$\mathrm{X}=$ Corporate Tax Planning $(\mathrm{CTP})=$ Independent Variable

$\mathrm{x}_{1}=$ Effective Tax Rate $($ ETR $)=$ Tax Paid/Profit Before Tax

$\mathrm{x}_{2}=$ Thin-capitalization (TCA)

$\mathrm{x}_{3}=$ Capital Intensity (CAI)

$\mathrm{x}_{4}=$ Firm Size (FS)

Hypothesis One

$\mathrm{y}_{1}=\mathrm{f}\left(\mathrm{x}_{1}\right)$

$$
\text { ROCE }=\mathrm{f}(\text { ETR, CAI, TCA, FS })
$$

$$
\mathrm{ROCE}_{\text {it }}=\beta_{0}+\beta_{1} \mathrm{ETR}_{\mathrm{it}}+\beta_{2} \mathrm{CAI}_{\mathrm{it}}+\beta 3 \mathrm{TCA}_{\mathrm{it}}+\varepsilon_{\mathrm{it}}
$$

Hypothesis Two

$$
\begin{aligned}
& y_{2}=f\left(x_{2}\right) \\
& y_{2}=f(E T R, \text { CAL, TCA, FS }) \\
& \text { ROA }_{i t}=\beta_{0}+\beta_{1} \text { ETR }_{i t}+\beta_{2} \mathrm{CAI}_{i t}+\beta 3 \mathrm{TCA}_{\text {it }}+\varepsilon_{i t}
\end{aligned}
$$

Hypothesis Three

$$
\begin{gathered}
\mathrm{y}_{3}=\mathrm{f}\left(\mathrm{x}_{3}\right) \\
\mathrm{y}_{3}=\mathrm{f}(\mathrm{ETR}, \mathrm{CAL}, \mathrm{TCA}, \mathrm{FS}) \\
\mathrm{ROE}_{\mathrm{it}}=\beta_{0}+\beta_{1} \mathrm{ETR}_{\mathrm{it}}+\beta_{2} \mathrm{CAI}_{\mathrm{it}}+\beta 3 \mathrm{TCA}_{\mathrm{it}}+\varepsilon_{\mathrm{it}}
\end{gathered}
$$

Hypothesis Four

$$
\begin{aligned}
\mathrm{y}_{4} & =\mathrm{f}\left(\mathrm{x}_{4}\right) \\
\mathrm{y}_{4} & =\mathrm{f}(\mathrm{ETR}, \mathrm{CAL}, \mathrm{TCA}, \mathrm{FS}) \\
\mathrm{EPS}_{\mathrm{it}} & =\beta_{0}+\beta_{1} \mathrm{ETR}_{\mathrm{it}}+\beta_{2} \mathrm{CAI}_{\mathrm{it}}+\beta 3 \mathrm{TCA}_{\mathrm{it}}+\varepsilon_{\text {it }}
\end{aligned}
$$

The models can be estimated using pooled, fixed effects and random effects estimators. A pooled estimator assumes that the intercepts ( $\alpha$ 's) and the residuals are constant across $\mathrm{s}$ and time. With this assumption, the models can be estimated using the ordinary Least Square (OLS).

When fixed effects are assumed, then the error becomes: $\epsilon_{\mathrm{it}}$ $=\mu_{\mathrm{i}+} \mathrm{v}_{\mathrm{it}}$

Where:

$\mu_{\mathrm{i}}$ is the unobserved individual- specific effects which do not vary with time and $v_{i t}$ is the remaining error term. When a random effect estimator is employed, $\mu_{\mathrm{i}}$ now becomes random.

$$
v_{\mathrm{i}}+\mu_{\mathrm{it}}
$$

Where $v_{\mathrm{i}}$ is individual effects which is fixed through time but varies across firms and $\mu_{\mathrm{it}}$ is the error term.

Results and Discussion of Finding.

Test of Main Hypothesis

Research Objective Main Model: to evaluate the effect of corporate tax planning on financial performance of quoted food and beverages firms in Nigeria.

Research Question Main Model: What is the impact of corporate tax planning on the financial performance of quoted foods and beverages firm in Nigeria?

Research Hypothesis Main Model: Corporate tax planning does not have significant effect on financial performance of quoted food and beverages firms in Nigeria.

Table 2. Regression Estimate for Main Model.

\begin{tabular}{lllll}
\hline Variable & Coefficient & Std Error & t-Stat. & Prob. \\
\hline C & .3102123 & .3208991 & 0.97 & 0.334 \\
ETR & -.1624373 & .1281571 & -1.27 & 0.205 \\
CAI & -.2762188 & .1600743 & -1.73 & 0.084 \\
TCA & .575068 & .5165677 & 1.11 & 0.266 \\
F-Statistic & 8.81 & & & \\
Prob. (F-Stat) & 0.0383 & & & \\
R squared & 0.0887 & & & \\
Adjusted R squared & 0.0689 & & & \\
\hline
\end{tabular}

Dependent Variable: financial performance

Main Model

$$
\begin{gathered}
\mathrm{FPM}=\mathrm{f}(\mathrm{ETR}, \mathrm{CAI}, \mathrm{TCA}, \mathrm{FS}) \\
\mathrm{FPM}_{\mathrm{it}}=\beta_{0}+\beta_{1} \mathrm{ETR}_{\mathrm{it}}+\beta_{2} \mathrm{CAI}_{\mathrm{it}}+\beta_{3} \mathrm{TCA}_{\mathrm{it}}+\beta_{4} \mathrm{FS}_{\mathrm{it}}+\varepsilon_{\mathrm{it}} \\
\mathrm{FPM}_{\mathrm{it}}=0.310212-0.162437 \mathrm{ETR}_{\mathrm{it}}-0.276219 \mathrm{CAI}_{\mathrm{it}}+0 . \\
575068 \mathrm{TCA}_{\mathrm{it}}+\beta_{4} \mathrm{FS}_{\mathrm{it}}+\varepsilon_{\mathrm{it}}
\end{gathered}
$$

The regression estimate of the main model shows that corporate tax planning is measured by effective tax rate (ETR) capital intensity (CAI), and thin capitalization (TCA), while financial performance is measured by return on capital employed financial performance. Thin capitalization (TCA) has negative effect on financial performance measured by return on capital employed financial performance. This is indicated by 
the signs of the coefficient. ( $\beta_{0}=0.3102123 ; \beta_{1}=-0.1624373$; $\left.\beta_{2}=-0.2762188 ; \beta_{3}=0.575068\right)$. Also, effective tax rate has a negative insignificant effect on financial performance $(\beta=$ -0.16244, $t=-1.27, p=0.205$ ), capital intensity has a negative significant effect on financial performance $(\beta=-0.27622, t=$ -1.73, $p=0.084)$, thin capitalisation has a positive significant effect on financial performance $(\beta=0.57507, t=1.11, p=0.266)$. This implies that only $\beta_{3}$ result is consistent with a-priori expectations that corporate tax planning will have a positive effect on financial performance.

The adjusted $R^{2}$ of the model showed that $6.9 \%$ of the variations in profitability of sampled food and beverages companies can be attributed to corporate tax planning proxies used in this study, while the remaining $91.1 \%$ of the variations in profitability of selected companies are caused by other factors not included in this model. However, the overall f-statistics is 8.81 with a probability value of 0.0383 which indicates that the explanatory variables of effective tax rate (ETR), thin-capitalization (TCA), capital intensity (CAI) and firm size (FS) have statistically significant effect on the dependent variable because the probability of f-statistics is less than $5 \%$, the level of significance adopted for this study.

A findings revealed that tax planning had a negative significant impact on the value of the firm; also, this study argued that tax planning affects negatively firm's value due to higher agency costs [4].

\section{Conclusion}

This study examined the effect of corporate tax planning financial performance of food and beverage firms in Nigeria. Numerical description of all variables under study was captured to depict the movement of values and determine the fluctuations of each of the independent variables with the dependent variables, also moderated by a variable.

Findings of this study therefore provide insight into the effect of corporate tax planning measured by effective tax rate, capital intensity, and thin capitalization on financial performance measured by return on capital employed, return of assets, return on equity and earnings per share of food and beverage firms in Nigeria for the period between 2008 and 2017. It also provides an affirmation of the extent to which the variations in the dependent variable are caused by the independent variables covered in the models as depicted by the R-squared and adjusted R-squared.

Thus, the study concluded that having found a significant relationship between corporate tax planning and financial performance in the food and beverage industry. Abuse of the tax planning mechanism and also high tax rate and challenges facing the tax system in Nigeria might be responsible for the negative relationship some measures of tax planning have with some measure of financial performance.

\section{Recommendations}

Based on the findings and conclusions of this study, the following recommendations are made to policy makers, and academia:
The existence of a positive relationship with thin capitalization and most measures of financial performance is an indication that companies can maximize thin capitalization in order to improve their financial performance. A collaboration between the Federal Inland Revenue Service, Corporate Affairs Commission and the Organised Private Sector groups like the various Chamber of Commerce should evolve a policy and procedure to avoid abuse and its negative impact.

Firms should avail themselves with various corporate tax planning mechanism and optimally utilize the best option that will enhance the performance of the company. This is possible with engagement of independent professional qualified tax consultant to review the available options and consequences.

Tax planning is not an absolute policy prescription for all firms; it depends to a greater extent on the associated benefits involved. Hence, it is recommended that Firms should ensure that proper analysis of the cost and benefits is done before embarking on it.

Firms can deal in tax favoured or tax -exempt investments as a mean of tax planning and this can be done with the pre-engagement of applicable Tax statutes and authorities, including reliance on decided court cases.

Corporate tax planning should be done in line with proper corporate governance mechanism in other to avoid earnings management. This can be internally initiated with suitably qualified tax experts.

\section{References}

[1] Abiola, J., \& Asiweh, M. (2012). Impact of tax administration on government revenue in a developing economy-a case study of Nigeria. International Journal of business and social science, $3(8)$.

[2] Adeyemi a. Adekunle and samson Disu (2018) Contemporary issues in corporate income tax in Nigeria - a review of precept and practice European Journal of Accounting, Auditing and finance research Vol.6, no.4, pp.59-78, may 2018

[3] Adkins, Matchet \& Toy. (2010). EPS - the holy grail or red herring of $\mathrm{M} \& \mathrm{~A}$ analysis. Technical update, February.

[4] Aganyo C. A. (2014). The Effects of Corporate Tax Planning on Firm Value for Companies Listed at the Nairobi Securities Exchange. Master's thesis. University of Nairobi, Kenya.

[5] Ayman Mansour Khalaf Alkhazaleh, M. Al-dwiry (2018). To What Extent Does Financial Leasing Has Impact on the Financial Performance of Islamic Banks: A Case Study of Jordan.

[6] Babalola (2013). The Effect of Firm Size on Firms Profitability in Nigeria. Journal of Economics and Sustainable Development Vol. 4, No.5,

[7] Bammeke, S. A. (2012). Tax implications of the ongoing banking sector reforms in Nigeria. Paper delivered at ICAN 2012 MCPE (Tax Practice Sector), Lagos, March 28 - 29

[8] Bayaraa, Batchimeg. (2017). Financial Performance Determinants of Organizations: The Case of Mongolian Companies. Journal of Competitiveness. 9. 22-33. 
[9] Buettner, T., Overesch, M., Schreiber, U., \& Wamser, G. (2012) The impact of thin capitalization rules on the capital structure of multinational firms. Journal of public Economic; 96, 930-938.

[10] Chen KP, \& Chu CYC (2005). Internal Control vs. External Manipulation:A model of corporate income tax evasion. RAND Journal of Economics 36(4):151-164

[11] Crocker and Slemrod (2005). Corporate Tax Evasion with Agency Cost. Journal of Public Economics, 2005, v89(9-10)

[12] Dada, S. 0. \& Adetola, R. (2017). TAX PLANNING AND FIRMS' PERFORMANCE IN NIGERIA. International Journal of Advance Research, 5(5). 1950-1956.

[13] Deloitte (2017). The new voluntary asset and income declaration scheme in Nigeria. Tax Regulatory Services 3 July 2017

[14] Dragota, V., Tatu, L., Pele, D., Vintila, N. and Semenescu, A. (2010). 'Capital Budgeting: The Romanian University Professors' Points of View', The Review of Finance and Banking, 2(2), pp. 95-102.

[15] Farah, N., Farrukh, I. and Faizan, N. (2016). Financial Performance of Firms: Evidence from Pakistan Cement Industry. Journal of Teaching and Education, 5, 81-94.

[16] Ferede, Ergete \& Dahlby, Bev. (2012). The Impact of Tax Cuts on Economic Growth: Evidence from the Canadian Provinces. National Tax Journal. 65. 563-594. 10.17310/ntj.2012.3.03.

[17] Garanina, T., \& Petrova, O. (2015). Relationship between liquidity, cash conversion cycle and returns of Russian companies. Korporativnye finansy $=$ Journal of Corporate Finance Research, 9(1), 33-40.

[18] Gilbert Cette \& Jimmy Lopez \& Jacques Mairesse, 2016."Labour Market Regulations and Capital Intensity," NBER Working Papers 22603, National Bureau of Economic Research, Inc.

[19] Graham, J. R., Campbell, R. H. \& Rajgopal, S. (2005), The economic implications of corporate financial reporting. Working paper, 11 January, Available at SSRN: https://ssrn.com/abstract $=647705$

[20] Gravelle, J. G., \& Marples, D. J. (2014). Tax rates and economic growth. Washington, DC: Congressional Research Service.

[21] Gupta, Sanjay \& Newberry, Kaye. (1997). Determinants of the Variability in Corporate Effective Tax Rate. Journal of Accounting and Public Policy. 16. 1-34.

[22] Ibrahim, Nabil. (2012). A proposed model to measure the impact of tax planning upon the financial performance of joint stock companies listed in the Egyptian financial market (A field empirical study). A study submitted to the conference of the Egyptian tax association that was held on 16th and 17th, September 2012 titled as "the future tax system and its impact upon economy and investment".

[23] Isabwa Harwood Kajirwa \& Omete F. Ikapel (2016). Operating Lease financing and financial Performance of State owned sugar manufacturingfirms in Kenya. International Journal of Re s earch in Finance and Marke ting Vol. 6 Issue 9, pp. 56 62.

[24] James O. Abiola \& Moses Asiweh (2012). Impact of Tax Administration on Government Revenue in a Developing
Economy - A Case Study of Nigeria. International Journal of Business and Social Science Vol. 3 No. 8

[25] Junaidu \& Hauwa (2018). Corporate Tax and Financial Performance of Listed Nigerian Consumer Goods. Journal of Accounting and Financial Management Vol. 4 No.4

[26] Ikpefan, O. A. \& Owolabi, F. (2014). Working capital management and profitability of the manufacturing sector: An empirical investigation of Nestle Nigeria plc and Cadbury Nigeria plc. Global Journal of Management and Business Research, 14(4).

[27] Kawor, S \& Kportorgbi, H. k. (2014). Effect of tax planning on firms' market performance: evidence from listed firms in Ghana. International Journal of Economics and Finance, 6(3), $162-168$.

[28] Khalid, A. A. A., Mohammad, A. F. A. \& Firas, N. R. H. (2017) The Impact of Tax Planning in Industrial Public Joint Stock Companies upon the Performance of the Industrial Companies Listed in the Amman Stock Exchange Market. Accounting and Finance Research, 6(2). 12-25.

[29] Khan, M. M. \& Safiuddin, S. K. (2016). Liquidity and profitability performance analysis of select pharmaceutical companies. International Journal of Science Technology and Management, 5(1).

[30] Knesl, J. (2018). Capital intensity and investment shocks: Implications for stock returns. SSRN Electronic Journal, 1(1), 1-62. DOI: 10.2139/ssrn.3019782.

[31] Li, Frank \& Dang, Chongyu. (2013). Measuring Firm Size in Empirical Corporate Finance. Journal of Banking \& Finance. 2018 forthcoming. 10.2139/ssrn.2345506

[32] Madugba, J. U., Ogbonnaya, A. K. \& Okpe I. I. (2016). An assessment of the casual relationship between economic growth and indirect taxes in Nigeria. International Journal of Development and Economic Sustainability Vol.4, No.5, pp.56-65.

[33] Maiga, S. (2015). The Impact of Tax Collection in Achieving Revenue Targets: The Directorate General of Taxes of Mali Case Study. Theoretical Economics Letters, 5(1). 403-409.

[34] Mathew Olusanya Gbonjubola(2016). 'Transfer Pricing and Thin Capitalization'. (Paper delivered at the Chartered Institute of Taxation of Nigeria (CITN) 2016 Tax Conference).

[35] Mohammad, R. P., Mahmoud, S., \& Ensieh, K. (2013). The study of relationship between capital intensity and finanacial leverage with degree of financial distress in companies listed in Tehran Stock Exchange. European Journal of Operational Research, 4(11). 3830-3839.

[36] Nwaobia, A. N. (2014). Tax Planning and corporate financial performance of selected manufacturing companies in Nigeria. IJRDO-Journal of Business Management, 1(4), 21-34.

[37] Nwaobia, A. N., \& Jayeoba, O. O. (2016). Tax planning and firms' liquidity. IJRDO-Journal of Business Management, 1(4), 21-34.

[38] Nwaobia, A. N., Kwarbai, J. D., \& Ogundajo, G. O. (2016). Tax planning and firm value: Empirical evidence from Nigerian consumer goods industrial sector. Research Journal of Finance and Accounting, 7 (12), $172-183$. 
[39] Olaoye Clement Olatunji\& Bamisaye Theresa Omolade(2018). Deferred tax and financial performance of firms in Nigeria. Journal of Business Administration and Management Sciences Research Vol. 7(2), pp. 050-058.

[40] Ogundajo, G. O. and Onakoya, A. B. (2016). Tax planning and financial performance of Nigerian manufacturing companies. International Journal of Advanced Academic Research (Social \& Management Sciences), 2(7). 64-80.

[41] Ohlson, J. A. \& Juettner-Nauroth, B. E. (2005). Expected EPS and EPS growth as determinants of value. Review of Accounting Studies, 10(1). 349-365.

[42] Onyekwelu, U, L., Nnadi, C. S. \& Iyidiobi, F. E. (2018). Evaluation of Firms' Corporate Financial Indicators and Operational Performance of Selected Firms in Nigeria. Research Journal of Finance and Accounting, 9(4), 20-29.

[43] Owolabi, S. A. \& Makinde, O. G. (2012). The Effects of Strategic Planning On Corporate Performance In University Education: A Study Of Babcock University Kuwait Chapter Of Arabian Journal Of Business And Management Review 2(4), $28-44$.

[44] Pniowsky, J. (2010). Aggressive tax planning-How aggressive is too aggressive. Thompson Dorfman Sweatman LLP, 3, 1-3.

[45] Pradip Kumar Das(2017). Impact of Return on Capital Employed On Company Performance - An Introspection in India. Saudi Journal of Business and Management Studies.

[46] Pratama, A. (2017). Does corporate governance reduce thin capitalization practice? The case of Indonesian Manufacturing firms. Review of integrative Business and Economic Research. $6(4)$.

[47] Pendleton, A. (2019). Financial participation in Europe: opportunities and risks for employees. ETUI Research Paper-Policy Brief, 1.

[48] Rappaport, A. (2005). The economics of short-term performance obsession. Financial Analysts Journal, 61(3). 65-79.

[49] Salawu, R., Ogundipe, L., \& Yeye, O. (2017). Granger Causality between Corporate Tax Planning and Firm Value of
Non-Financial Quoted Companies in Nigeria. International Journal of Business and Social Science, 8(9). 91-103.

[50] Setiadharma \& Machali (2017). The effect of asset structure and firm size on firm value with capital structure as intervening variable. Journal of Business and Financial Affairs 6:4.

[51] Slemrod J (2004). The Economics of Corporate Tax Selfishness. National Tax Journal 57(4):877-899.

[52] Stickney, C. P., \& McGee, V. E. (1982). Effective corporate tax rates. The effect of size, capital intensity, leverage, and other factors. Journal of Accounting and Public Policy, 1, 125-152.

[53] Taboga, M. (2011), Under- and over-valuation of the stock market and cyclically adjusted earnings. International Finance, Vol. 14, No. 1, pp. 135-164.

[54] Tatu, Lucian \& Dragota, Victor \& Vintila, Nicoleta. (2011). An Observation on the Effective Tax Rate for Corporate Income in Romania. Economic computation and economic cybernetics studies and research / Academy of Economic Studies. 45. 91-106.

[55] Tsado, M. \& Gunu, U. (2016). Managers' perception of internal factors and their effect on corporate entrepreneurship: the case of Nigerian manufacturing industry. Economica, 12(4).

[56] Turner, F. J. (Ed.). (2017). Social work treatment: Interlocking theoretical approaches. Oxford University Press.

[57] Tye \& Nor (2018). Roles of tax planning in market valuation of corporate social responsibility. JournalCogent Business \& Management Volume 5, Issue 1.

[58] Yimbila, B. (2017). Tax planning, corporate governance and performance of banks in Ghana (Doctoral dissertation, University of Cape Coast).

[59] Zevenbergen, L. (2018). Firm performance and tax avoidance. Retrievedfromhttps://pdfs.semanticscholar.org/0429/edbfbe5d 511 ba9150ec76600df3055b4dda8.pdf

[60] Zwingina Christy Twaliwi \& Opusunju Michael Isaac (2017). Impact of Innovation on the Performance of Small and Medium Scale Enterprise in Gwagwalada, Abuja. International Journal of Entrepreneurial Development, Education and Science Research Vol. 4, No.1 